\title{
SURVEY OF ENTRANTS TO NURSE TRAINING SCHOOLS AND OF STUDENT-NURSE WASTAGE IN THE BIRMINGHAM REGION
}

\author{
BY \\ K. W. CROSS and DORIS L. A. HALL \\ Department of Medical Statistics, University of Birmingham and Birmingham Regional Hospital Board
}

\section{INTRODUCTION}

One of the most urgent problems confronting the National Health Service is that of providing sufficient nursing staff. It will be possible to maintain the hospitals at the existing level of efficiency only if it is possible to provide enough adequately trained nurses in future years. To a large extent the quality and quantity of the nursing staffs, as of the Health Service in general, must depend on how much the community can afford to spend.

Doubtless financial difficulties in Great Britain will restrict expenditure on the hospitals for several years to come, though annual salary increments with the rising cost of provisions, fuel, light, and water may involve greater expenditure. Meanwhile more lucrative opportunities in industry or government employment may adversely influence readiness to engage in nursing.

The hospitals cannot compete with industry or the civil service in so far as recruitment depends on remuneration offered; and the hours of duty required by a hospital are more exacting. Furthermore, we must not neglect population trends which affect not only the future pattern of hospitalized disease but also the potential reservoir of persons from which the nursing service draws its recruits. Current estimates show that in 1960 there will be almost half a million fewer females between the ages of 18 to 30 years inclusive, than in 1951.

For this reason alone we may expect that recruitment of women to the nursing services during the remaining years of this decade will present increasing difficulties.

\section{Shortage of Nursing Staff in the Birmingham Region}

What follows refers to nursing staff requirements in the Birmingham Hospital Region with special reference to:

(i) the number of beds not in use owing to nursing staff shortage;

(ii) the stated requirements of hospitals in terms of full-time staff equivalents.
It appears that 3,250 beds out of a total of 44,350 were not in use at the end of 1952, and lack of nursing staff accounted for almost 2,500 of these. Hence the overall bed availability could increase by 6 per cent if sufficient staff were available.

However, the number of unused beds is only a rough measure of the shortages, since staff requirements vary considerably by type of hospital, and beds do not necessarily go out of use when nurses are in short supply. Thus mental hospitals and mental deficiency institutions, where bed space is in great demand, though seriously short of staff, have relatively few beds not in use. This situation also exists at chronic sick hospitals and sanatoria, where shortage of nursing staff is also acute. On the other hand, the measure given by (ii) may well exaggerate a nursing staff shortage in so far as hospitals tend to fix their nursing establishments at an unduly optimistic level.

Hospitals in this Region employ 10,210 full-time and 2,850 part-time nurses, of whom 4,020 and 820 respectively are already trained. Their stated additional requirements are 4,100 full-time nurses (or full-time equivalents) of all grades, of whom 1,065 should be already trained. Out of this total the mental hospitals and mental deficiency institutions assess their requirements at 1,290 nurses, of whom 492 must be already trained. Without here attempting to assess more realistically the requirements of the hospital nursing services at the present time, it is probably true to say that all the trained staff available for employment are already in the Service, and that in certain types of hospital the present rate of recruitment and training of student nurses cannot even replace those due to retire during the remaining years of this decade. Meanwhile there is no prospect in the foreseeable future of any increase in the rate of recruitment. Hence it is of the utmost importance that those attracted to the hospital service shall remain in it. Only by recruitment and training of student nurses and by their retention in the hospital service shall we be able to safeguard the future.

Before undertaking this survey it was realized that student-nurse wastage varies with type of 
training school, and that the extent of this variation is much more important than the range of variation among hospitals of the same type. Whereas the latter is largely due to local conditions the former reflects differences with respect to facilities available, to the character and scope of training, and presumably to type of entrant. An indication of the magnitude of these differences was obtained from the report of the Working Party on the Recruitment and Training of Nurses, which gives inter alia an analysis of the estimated intake and wastage of student nurses over the period 1937 to 1943 . However, the pattern of nurse recruitment undoubtedly changed after the end of the war and a more up-todate analysis was deemed to be essential.

\section{Method of Collection ANd Source of DATA}

An exhaustive investigation of the problem of studentnurse wastage necessitates the collection of detailed information about the students entering training during a specified period, so that the progress of each student may be studied from the time of entering to that of leaving. With this end in view, two questionnaires were designed for use in the Birmingham Region; the one relating to the student and the other to the hospital providing the training. To allow a sufficient period for students to complete their training, the year chosen for the survey was 1946, and hospitals were asked to complete a questionnaire for every student entering training during that year.

Questionnaires were duly completed by all hospitals in the Birmingham Region with training schools. In what follows we consider what aspects of student-nurse wastage they elucidate, and the results of a detailed analysis of the type of person entering the schools during 1946 are also given. Not all information presumptively relevant to the inquiry was available on existing records, but the results obtained give clear indications of the relative importance of some circumstances which contribute to student wastage.

\section{Age of Students at Entry}

It will be recalled that under the Nurses Rules, Approval Instrument, 1951, the minimum age of entry for nurse training as from the first day of August, 1952, is 18 years. In view of the controversy which resulted from the application of this ruling and of its importance from our viewpoint here, we shall first consider age at entry. Table I shows, for each type of training, percentage age and sex distributions for students entering upon nurse training in 1946, the actual numbers involved being given at the foot of the columns.

As would be expected, the Table shows that for all types of training school male students started at a much later age than female students. This sex differential was accentuated in 1946 by the intake of male students in the older age groups from His Majesty's Forces. It is interesting to compare these results with those obtained from a survey of age of entry of student nurses to training in 1950 and 1951. If both sexes are considered together, the following proportions of students who entered the various types of training schools were under 18 years of age at entry:

\begin{tabular}{|c|c|c|c|c|c|c|c|}
\hline & & \multicolumn{2}{|c|}{1946} & \multicolumn{2}{|c|}{1950} & \multicolumn{2}{|c|}{1951} \\
\hline \multicolumn{2}{|c|}{$\begin{array}{c}\text { Type of } \\
\text { Training School }\end{array}$} & $\begin{array}{c}\text { No. } \\
\text { of } \\
\text { En- } \\
\text { trants }\end{array}$ & $\begin{array}{c}\text { Per } \\
\text { cent. } \\
\text { under } \\
18\end{array}$ & $\begin{array}{l}\text { No. } \\
\text { of } \\
\text { En- } \\
\text { trants }\end{array}$ & $\begin{array}{c}\text { Per } \\
\text { cent. } \\
\text { under } \\
18\end{array}$ & $\begin{array}{c}\text { No. } \\
\text { of } \\
\text { En- } \\
\text { trants }\end{array}$ & $\begin{array}{c}\text { Per } \\
\text { cent. } \\
\text { under } \\
18\end{array}$ \\
\hline $\begin{array}{l}\text { General } \quad \ldots \\
\text { Mental } \\
\text { Mental Deficiency } \\
\text { Fever } \quad \text {. } \\
\text { Affiliated } \quad \ldots\end{array}$ & $\begin{array}{l}\ddot{ } \\
\cdots \\
\cdots \\
\cdots\end{array}$ & $\begin{array}{r}866 \\
173 \\
68 \\
26 \\
158\end{array}$ & $\begin{array}{l}17 \cdot 8 \\
11 \cdot 6 \\
12 \cdot 0 \\
30 \cdot 7 \\
46 \cdot 8\end{array}$ & $\begin{array}{r}957 \\
153 \\
59 \\
70 \\
212\end{array}$ & $\begin{array}{l}34 \cdot 0 \\
11 \cdot 2 \\
10 \cdot 2 \\
64 \cdot 3 \\
61 \cdot 8\end{array}$ & $\begin{array}{r}888 \\
120 \\
33 \\
42 \\
172\end{array}$ & $\begin{array}{r}38 \cdot 2 \\
6 \cdot 7 \\
6 \cdot 1 \\
61 \cdot 9 \\
56 \cdot 4\end{array}$ \\
\hline All Types & $\ldots$ & 1,291 & $20 \cdot 8$ & 1,451 & $36 \cdot 2$ & 1,255 & $37 \cdot 6$ \\
\hline
\end{tabular}

TABLE I

AGE AT ENTRY TO NURSE TRAINING, BY SEX

Percentage Distributions by Type of Training School

\begin{tabular}{|c|c|c|c|c|c|c|c|c|c|c|c|c|c|c|c|c|}
\hline \multirow{3}{*}{$\begin{array}{c}\text { Age Group } \\
\text { (yrs.) }\end{array}$} & \multicolumn{14}{|c|}{ Type of Training School } & \multirow{2}{*}{\multicolumn{2}{|c|}{ Totals }} \\
\hline & \multicolumn{2}{|c|}{ General } & \multicolumn{2}{|c|}{ Mental } & \multicolumn{2}{|c|}{$\begin{array}{c}\text { Mental } \\
\text { Deficiency }\end{array}$} & \multicolumn{2}{|c|}{ Fever } & \multicolumn{2}{|c|}{ Tuberculosis } & \multicolumn{2}{|c|}{ Orthopaedic } & \multicolumn{2}{|c|}{ Ophthalmic } & & \\
\hline & Male & Female & Male & Female & Male & Female & Male & Female & Male & Female & Male & Female & Male & Female & $\overline{\text { Male }}$ & Female \\
\hline $\begin{array}{ll}\text { Under } 17 & \ldots \\
17- & \ldots \\
18- & \ldots \\
19- & \ldots \\
20-24 & \ldots \\
25-29 & \ldots \\
30- & \\
40 \text { and over } \\
\text { Not Known }\end{array}$ & $\begin{array}{c}\bar{Z} \\
\bar{Z} \\
34 \cdot 8 \\
21 \cdot 7 \\
43 \cdot 5 \\
=\end{array}$ & $\begin{array}{r}17 \cdot 1 \\
17 \cdot 2 \\
24 \cdot 4 \\
13 \cdot 9 \\
31 \cdot 5 \\
6 \cdot 8 \\
3 \cdot 4 \\
\frac{1 \cdot 7}{1 \cdot 7}\end{array}$ & $\begin{array}{r}1.4 \\
2.7 \\
2.7 \\
2.7 \\
29.7 \\
41.8 \\
17.6 \\
1.4 \\
-\end{array}$ & $\begin{array}{r}2 \cdot 0 \\
15 \cdot 2 \\
20 \cdot 2 \\
9 \cdot 1 \\
34 \cdot 4 \\
12 \cdot 1 \\
\frac{1}{1 \cdot 0} \\
6 \cdot 0\end{array}$ & $\begin{array}{r}\overline{7 \cdot 1} \\
7 \cdot 1 \\
2 \overline{-1} \\
26.5 \\
26 \cdot 2 \\
2 \cdot 4 \\
9 \cdot 5\end{array}$ & $\begin{array}{l}11 \cdot 5 \\
23 \cdot 1 \\
11.5 \\
3.9 \\
34 \cdot 6 \\
3.9 \\
11 \cdot 5 \\
=\end{array}$ & $\begin{array}{l}= \\
\bar{z} \\
= \\
=\end{array}$ & $\begin{array}{r}11 \cdot 5 \\
19 \cdot 2 \\
3.9 \\
23 \cdot 1 \\
26 \cdot 8 \\
7 \cdot 7 \\
3.9 \\
\frac{7.9}{3 \cdot 9}\end{array}$ & $\begin{array}{l}= \\
= \\
= \\
14 \cdot 3 \\
71 \cdot 4 \\
14 \cdot 3 \\
=\end{array}$ & $\begin{array}{r}6 \cdot 3 \\
9 \cdot 5 \\
14 \cdot 3 \\
17 \cdot 5 \\
25 \cdot 4 \\
15 \cdot 9 \\
3 \cdot 2 \\
1 \cdot 6 \\
6 \cdot 3\end{array}$ & $\begin{array}{l}\bar{z} \\
\bar{z} \\
\bar{z}\end{array}$ & $\begin{array}{r}31.4 \\
47.2 \\
11.4 \\
2.9 \\
5.7 \\
1.4 \\
= \\
=\end{array}$ & $\begin{array}{l}\bar{z} \\
\bar{z} \\
\bar{z} \\
=\end{array}$ & $\begin{array}{c}50 \cdot \overline{0} \\
5 \cdot 6 \\
11 \cdot 1 \\
33 \cdot 3 \\
= \\
= \\
=\end{array}$ & $\begin{array}{r}0 \cdot 7 \\
3 \cdot 4 \\
3.4 \\
1.4 \\
27.4 \\
35 \cdot 6 \\
24 \cdot 0 \\
1.4 \\
2.7\end{array}$ & $\begin{array}{r}3 \cdot 8 \\
19 \cdot 1 \\
21 \cdot 7 \\
12 \cdot 9 \\
29 \cdot 7 \\
7 \cdot 3 \\
3 \cdot 1 \\
0 \cdot 2 \\
2 \cdot 2\end{array}$ \\
\hline Totals & $\begin{array}{c}100 \cdot 0 \\
(23)\end{array}$ & $\begin{array}{r}100 \cdot 0 \\
(843)\end{array}$ & $\begin{array}{c}100 \cdot 0 \\
(74)\end{array}$ & $\begin{array}{r}100 \cdot 0 \\
(99)\end{array}$ & $\begin{array}{c}100 \cdot 0 \\
(42)\end{array}$ & $\begin{array}{c}100 \cdot 0 \\
(26)\end{array}$ & 二 & $\begin{array}{r}100 \cdot 0 \\
(26)\end{array}$ & $\begin{array}{c}100 \cdot 0 \\
(7)\end{array}$ & $\begin{array}{r}100 \cdot 0 \\
(63)\end{array}$ & - & $\begin{array}{r}100 \cdot 0 \\
(70)\end{array}$ & 二 & $\begin{array}{r}100 \cdot 0 \\
(18)\end{array}$ & $\begin{array}{r}100 \cdot 0 \\
(146)\end{array}$ & $\begin{array}{l}100 \cdot 0 \\
(1,145)\end{array}$ \\
\hline
\end{tabular}


TABLE II

AGE AT ENTRY AND RESULT OF TRAINING

\begin{tabular}{|c|c|c|c|c|c|c|c|c|c|c|c|c|c|c|c|c|}
\hline \multirow{3}{*}{$\begin{array}{c}\text { Age Group } \\
\text { (yrs) }\end{array}$} & \multicolumn{14}{|c|}{ Type of Training School } & \multirow{2}{*}{\multicolumn{2}{|c|}{ Total }} \\
\hline & \multicolumn{2}{|c|}{ General } & \multicolumn{2}{|c|}{ Mental } & \multicolumn{2}{|c|}{$\begin{array}{c}\text { Mental } \\
\text { Deficiency }\end{array}$} & \multicolumn{2}{|c|}{ Fever } & \multicolumn{2}{|c|}{ Tuberculosis } & \multicolumn{2}{|c|}{ Orthopaedic } & \multicolumn{2}{|c|}{ Ophthalmic } & & \\
\hline & $\begin{array}{l}\text { Total } \\
\text { Stu- } \\
\text { dents }\end{array}$ & $\begin{array}{c}\text { Per } \\
\text { cent. } \\
\text { Suc- } \\
\text { cessful }\end{array}$ & $\begin{array}{c}\text { Total } \\
\text { Stu- } \\
\text { dents }\end{array}$ & $\begin{array}{c}\text { Per } \\
\text { cent. } \\
\text { Suc- } \\
\text { cessful }\end{array}$ & $\begin{array}{l}\text { Total } \\
\text { Stu- } \\
\text { dents }\end{array}$ & $\begin{array}{c}\text { Per } \\
\text { cent. } \\
\text { Suc- } \\
\text { cessful }\end{array}$ & $\begin{array}{l}\text { Total } \\
\text { Stu- } \\
\text { dents }\end{array}$ & $\begin{array}{c}\text { Per } \\
\text { cent. } \\
\text { Suc- } \\
\text { cessful }\end{array}$ & $\begin{array}{l}\text { Total } \\
\text { Stu- } \\
\text { dents }\end{array}$ & $\begin{array}{c}\text { Per } \\
\text { cent. } \\
\text { Suc- } \\
\text { cessful }\end{array}$ & $\begin{array}{c}\text { Total } \\
\text { Stu- } \\
\text { dents }\end{array}$ & $\begin{array}{c}\text { Per } \\
\text { cent. } \\
\text { Suc- } \\
\text { cessful }\end{array}$ & $\begin{array}{l}\text { Total } \\
\text { Stu- } \\
\text { dents }\end{array}$ & $\begin{array}{c}\text { Per } \\
\text { cent. } \\
\text { Suc- } \\
\text { cessful }\end{array}$ & $\begin{array}{l}\text { Total } \\
\text { Stu- } \\
\text { dents }\end{array}$ & $\begin{array}{c}\text { Per } \\
\text { cent. } \\
\text { Suc- } \\
\text { cessful }\end{array}$ \\
\hline $\begin{array}{ll}\text { Under } 18 & \ldots \\
18- & \ldots \\
19- & \ldots \\
20-24 & \ldots \\
25-29 & \cdots \\
30- & \cdots \\
40 \text { and over }\end{array}$ & $\begin{array}{r}154 \\
207 \\
117 \\
274 \\
63 \\
39 \\
-\end{array}$ & $\begin{array}{l}39 \cdot 0 \\
51 \cdot 7 \\
46 \cdot 2 \\
48 \cdot 2 \\
50 \cdot 8 \\
56 \cdot 4 \\
-\end{array}$ & $\begin{array}{r}20 \\
22 \\
11 \\
56 \\
43 \\
13 \\
2\end{array}$ & $\begin{array}{r}10 \cdot 0 \\
4 \cdot 5 \\
0 \cdot 0 \\
14 \cdot 3 \\
32 \cdot 6 \\
53 \cdot 8 \\
0 \cdot 0\end{array}$ & $\begin{array}{r}12 \\
6 \\
1 \\
18 \\
12 \\
14 \\
1\end{array}$ & $\begin{array}{r}8 \cdot 3 \\
0 \cdot 0 \\
0 \cdot 0 \\
27 \cdot 8 \\
16 \cdot 7 \\
50 \cdot 0 \\
0 \cdot 0\end{array}$ & $\begin{array}{l}8 \\
1 \\
6 \\
7 \\
2 \\
1 \\
-\end{array}$ & $\begin{array}{r}37 \cdot 5 \\
100 \cdot 0 \\
33 \cdot 3 \\
57 \cdot 2 \\
100 \cdot 0 \\
0 \cdot 0 \\
\end{array}$ & $\begin{array}{r}8 \\
9 \\
12 \\
18 \\
15 \\
3 \\
1\end{array}$ & $\begin{array}{r}25 \cdot 0 \\
22 \cdot 2 \\
58 \cdot 3 \\
27 \cdot 8 \\
33 \cdot 3 \\
66 \cdot 7 \\
0 \cdot 0\end{array}$ & $\begin{array}{r}55 \\
8 \\
2 \\
4 \\
1 \\
-\end{array}$ & $\begin{array}{r}49 \cdot 1 \\
42 \cdot 9 \\
0 \cdot 0 \\
33 \cdot 3 \\
0 \cdot 0 \\
-\end{array}$ & $\begin{array}{l}9 \\
1 \\
2 \\
6 \\
- \\
-\end{array}$ & $\begin{array}{r}22 \cdot 2 \\
0 \cdot 0 \\
100 \cdot 0 \\
50 \cdot 0 \\
- \\
-\end{array}$ & $\begin{array}{r}266 \\
254 \\
151 \\
383 \\
136 \\
70 \\
4\end{array}$ & $\begin{array}{r}36 \cdot 5 \\
44 \cdot 9 \\
43 \cdot 0 \\
41 \cdot 3 \\
40 \cdot 4 \\
54 \cdot 3 \\
0 \cdot 0\end{array}$ \\
\hline Totals* & 854 & $47 \cdot 7$ & 167 & $19 \cdot 2$ & 64 & $23 \cdot 4$ & 25 & $48 \cdot 0$ & 66 & $34 \cdot 8$ & 70 & $44 \cdot 3$ & 18 & $38 \cdot 9$ & 1,264 & $41 \cdot 7$ \\
\hline
\end{tabular}

* These totals exclude students whose ages were unknown

Differences between the proportions exhibited for 1951 and 1946 are most spectacular in the case of both the general and the fever training schools, and it is of particular interest to examine the results of training for students in various age groups. The results of this analysis are given in Table II.

In general training schools the proportion successful is lowest in the first age group, viz., under the age of 18. The figures for mental training schools are even more striking: of a total of 53 students entering under the age of 20 only three completed training, and in the case of mental deficiency training only one student out of nineteen who entered under the age of 20 was successful. In view of the small numbers involved, it is difficult to draw any firm conclusions as regards fever and ophthalmic training schools. If we consider all schools together, it would appear that the student entering training under the age of 18 is even more likely to fall out than the older student. The application of the minimum age bar would seem to be particularly relevant to mental hospitals and mental defective institutions.

\section{Educational Background}

A second circumstance of particular relevance to the inquiry is the educational background of the student. As one criterion, the age of completion of full-time education was requested for each student (Table III). Unfortunately this information was not available in respect of 24 per cent. of all students entering training in 1946.

In training schools as a whole, a high proportion of students $(36 \cdot 2$ per cent.) left school at the age of 14 and hence presumptively had only an elementary education and certainly no academic qualifications. This preponderance was particularly noticeable among students entering mental and mental deficiency training schools. A further $137(10.5$ per cent.) students were known to have left school at 15 and although some of these had attended secondary or grammar schools, only five had obtained school certificate or matriculated. Thus it may be said that almost half the students entering nursing in 1946 were known to have received only the minimum of education. Table III also shows that $17 \cdot 7$ per cent.

TABLE III

AGE AT COMPLETION OF FULL-TIME EDUCATION

Percentage Distributions by Type of Training School

\begin{tabular}{|c|c|c|c|c|c|c|c|c|c|}
\hline \multirow{2}{*}{\multicolumn{2}{|c|}{ Age (yrs) }} & \multicolumn{7}{|c|}{ Type of Training School } & \multirow{2}{*}{ Total } \\
\hline & & General & Mental & $\begin{array}{c}\text { Mental } \\
\text { Deficiency }\end{array}$ & Fever & Tuberculosis & Orthopaedic & Ophthalmic & \\
\hline 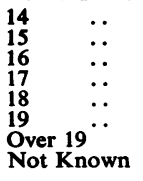 & $\begin{array}{l}\because \\
\because \\
\because \\
\because \\
\therefore \\
\therefore\end{array}$ & $\begin{array}{r}33 \cdot 7 \\
11 \cdot 1 \\
20 \cdot 4 \\
7 \cdot 8 \\
3 \cdot 8 \\
0 \cdot 5 \\
0 \cdot 3 \\
22 \cdot 4\end{array}$ & $\begin{array}{r}53 \cdot 7 \\
8 \cdot 1 \\
8 \cdot 1 \\
2 \cdot 3 \\
1 \cdot 2 \\
\overline{0} \cdot 6 \\
26 \cdot 0\end{array}$ & $\begin{array}{r}73 \cdot 6 \\
11 \cdot 7 \\
2 \cdot 9 \\
1 \cdot 5 \\
\frac{1}{1} \cdot 5 \\
\frac{8}{8} \cdot 8\end{array}$ & $\begin{array}{l}7 \cdot 7 \\
7 \cdot 7 \\
15 \cdot 4 \\
\overline{3} \cdot 8 \\
\overline{7} \\
65 \cdot 4\end{array}$ & $\begin{array}{l}27 \cdot 2 \\
17 \cdot 1 \\
10 \cdot 0 \\
4 \cdot 3 \\
= \\
\overline{41} \cdot 4\end{array}$ & $\begin{array}{l}8 \cdot 6 \\
4 \cdot 3 \\
25 \cdot 7 \\
37 \cdot 2 \\
1 \cdot 4 \\
= \\
22 \cdot 8\end{array}$ & $\begin{array}{l}27 \cdot 8 \\
5 \cdot 5 \\
39 \cdot 0 \\
5 \cdot 5 \\
11 \cdot 1 \\
\frac{7}{11} \cdot 1\end{array}$ & $\begin{array}{r}36 \cdot 2 \\
10.5 \\
17.7 \\
8 \cdot 0 \\
3.0 \\
0.4 \\
0.3 \\
23.9\end{array}$ \\
\hline Totals .. & .. & $\begin{array}{l}100 \cdot 0 \\
(866)\end{array}$ & $\begin{array}{l}100 \cdot 0 \\
(173)\end{array}$ & $\begin{array}{l}100 \cdot 0 \\
(68)\end{array}$ & $\begin{array}{l}100 \cdot 0 \\
(26)\end{array}$ & $\begin{array}{l}100 \cdot 0 \\
(70)\end{array}$ & $\begin{array}{l}100 \cdot 0 \\
(70)\end{array}$ & $\begin{array}{l}100 \cdot 0 \\
(18)\end{array}$ & $\begin{array}{r}100 \cdot 0 \\
(1,291)\end{array}$ \\
\hline
\end{tabular}


of all students were known to have left school at age 16,8 per cent. at 17 , and only 3.7 per cent. at 18 or over. Most of those who left school at 16 were known to have had a secondary or grammar school education, but 54 per cent. held no certificate qualification.

It is difficult to draw conclusions with respect to individual training schools (except the general and mental training schools) because of the small numbers involved. However, to complete our picture with regard to the bearing of educational background on student wastage, an analysis of results of training by type of background is given in Table IV for all students irrespective of training school. This Table shows the numbers in the major educational groups and also the proportion successful in each class. Only students whose standard of education is known (i.e., year of completion, type of school, and qualification attained) are included. It will be noticed that in every age category the proportion of successes is considerably higher among students possessing school certificate or matriculation than among those with no qualification; percentages based upon very small numbers are shown in brackets. The possession of such a qualification appears to be a more important factor than the time spent on education, since the proportion of successful students without qualification varies little with age of completion of full-time education. These results show that the best type of student from the educational viewpoint is the one who stayed at a secondary or grammar school until 16 or 17 years of age and obtained a school certificate.

\section{Pre-Nursing Courses and Previous EXPERIENCE}

In 1946 very few pre-nursing courses appear to have been run by education authorities. Only nine students had attended such courses, and of these seven completed training. No conclusions regarding the value of such courses can therefore be made at this stage. However, an analysis of students who had nursing experience before starting to train proved to be far more rewarding. We may distinguish three groups:

(i) students who previously obtained a nursing qualification;

TABLE IV

RESULT OF TRAINING BY EDUCATIONAL BACKGROUND

\begin{tabular}{|c|c|c|c|c|c|c|}
\hline \multirow{2}{*}{\multicolumn{3}{|c|}{$\begin{array}{c}\text { Age at } \\
\text { Completion } \\
\text { of Full-Time } \\
\text { Education (yrs) }\end{array}$}} & \multicolumn{2}{|c|}{ Educational Grade } & \multirow{3}{*}{$\begin{array}{c}\begin{array}{c}\text { Total } \\
\text { Students }\end{array} \\
467\end{array}$} & \multirow{3}{*}{$\begin{array}{c}\text { Per cent. } \\
\text { Successful } \\
37 \cdot 9\end{array}$} \\
\hline & & & Type of School & Qualification & & \\
\hline$\overline{14}$ & $\ldots$ & .. & Elementary only & None & & \\
\hline \multirow[t]{2}{*}{15} & $\ldots$ & $\ldots$ & $\begin{array}{l}\text { Elementary only } \\
\text { Elementary and Secondary or Grammar } \\
\text { Elementary and Technical or Commercial } \\
\text { College } \\
\text { Other }\end{array}$ & $\begin{array}{l}\text { None } \\
\text { None } \\
\text { School Certificate or Matriculation } \\
\text { None } \\
\text { None }\end{array}$ & $\begin{array}{r}53 \\
37 \\
5 \\
16 \\
10\end{array}$ & $\begin{array}{c}41 \cdot 5 \\
35 \cdot 1 \\
(60 \cdot 0) \\
50 \cdot 0 \\
40 \cdot 0\end{array}$ \\
\hline & & & All Schools & $\begin{array}{l}\text { None } \\
\text { School Certificate or Matriculation }\end{array}$ & $\begin{array}{r}116 \\
5\end{array}$ & $\begin{array}{c}40 \cdot 5 \\
(60 \cdot 0)\end{array}$ \\
\hline \multirow[t]{2}{*}{16} & . & . & $\begin{array}{l}\text { Elementary and Secondary or Grammar } \\
\text { Secondary or Grammar only } \\
\text { Elementary and Technical or Commercial } \\
\text { College } \\
\text { Other }\end{array}$ & $\begin{array}{l}\text { None } \\
\text { School Certificate or Matriculation } \\
\text { None } \\
\text { School Certificate or Matriculation } \\
\text { None } \\
\text { School Certificate or Matriculation } \\
\text { None }\end{array}$ & $\begin{array}{r}67 \\
62 \\
18 \\
11 \\
18 \\
2 \\
16\end{array}$ & $\begin{array}{l}47 \cdot 8 \\
69 \cdot 3 \\
61 \cdot 1 \\
63 \cdot 6 \\
33 \cdot 3 \\
(50 \cdot 0) \\
37 \cdot 5\end{array}$ \\
\hline & & & All Schools & $\begin{array}{l}\text { None } \\
\text { School Certificate or Matriculation }\end{array}$ & $\begin{array}{r}119 \\
75\end{array}$ & $\begin{array}{l}46 \cdot 2 \\
68 \cdot 0\end{array}$ \\
\hline \multirow[t]{2}{*}{$\overline{17}$} & . & $\cdots$ & $\begin{array}{l}\text { Elementary and Secondary or Grammar } \\
\text { Secondary or Grammar only } \\
\text { Other }\end{array}$ & $\begin{array}{l}\text { None } \\
\text { School Certificate or Matriculation } \\
\text { None } \\
\text { School Certificate or Matriculation } \\
\text { None } \\
\text { School Certificate or Matriculation }\end{array}$ & $\begin{array}{r}16 \\
25 \\
11 \\
24 \\
10 \\
5\end{array}$ & $\begin{array}{c}50.0 \\
84.0 \\
36.4 \\
66.7 \\
40.0 \\
(60.0)\end{array}$ \\
\hline & & & All Schools & $\begin{array}{l}\text { None } \\
\text { School Certificate or Matriculation }\end{array}$ & $\begin{array}{l}37 \\
54\end{array}$ & $\begin{array}{l}43 \cdot 2 \\
74 \cdot 1\end{array}$ \\
\hline \multicolumn{3}{|c|}{18 and over } & All Schools & $\begin{array}{l}\text { None } \\
\text { School Certificate or Matriculation and } \\
\text { higher qualifications }\end{array}$ & $\begin{array}{l}16 \\
23\end{array}$ & $\begin{array}{l}37 \cdot 5 \\
65 \cdot 2\end{array}$ \\
\hline
\end{tabular}


(ii) students with previous hospital experience but no qualification;

(iii) students with nursing experience other than in hospital.

In 1946, 98 students who had previously obtained a nursing qualification proceeded to further training; of these 72 ( 73.5 per cent.) completed training, and, as would be expected, this proportion is significantly greater than the corresponding proportion (40.9 per cent.) for all students. There were 195 students in the second group, of whom $90(46 \cdot 1$ per cent.) completed training. There were 105 students in the third group, of whom 54 (51.4 per cent.) completed training. The inclusion in the last group of an appreciable number of students who had previously served in the Royal Army Medical Corps is one reason for the relatively high success rate.

We had hoped to make a breakdown with regard to previous occupation of students without previous hospital nursing experience, but this information is not often recorded by hospitals. However, three broad headings (clerical, industrial, and domestic) account for about 60 per cent. of all those specified. Whereas a large proportion of students entering general training were recorded as having previously had a clerical occupation, most of those entering the mental training schools, whose previous occupations were known, had been employed in industry, domestic work, or H.M. Forces.
7. Degree of AND Reasons for Wastage

Having reviewed certain aspects of the type of student nurse entering training schools in 1946, and having analysed separately the part that each plays in student wastage, we may here consider the overall wastage figures for the various types of training school. The reasons for wastage are classified under two headings:

(i) those relevant to students requested to leave,

(ii) those relevant to students who left of their own accord.

These reasons are shown in Table $\mathrm{V}$ with the proportion of successful students. The Table first shows that for training schools taken as a whole only 41 students out of every 100 complete training. This result agrees fairly closely with the findings of the Working Party set up in 1946 to examine the recruitment and training of nurses:

out of every hundred student nurses that enter training not more than fifty remain at the end of the training period, and in many hospitals not more than thirty remain.

The wastage rates calculated by the Working Party for four types of training school are: General (37 per cent.), Mental (82 per cent.), Infectious Diseases (56 per cent.), Tuberculosis Sanatoria (65 per cent.). Except in the case of the general

TABLE V

DISPOSAL OF ALL STUDENTS

Percentage Distributions by Type of Training School

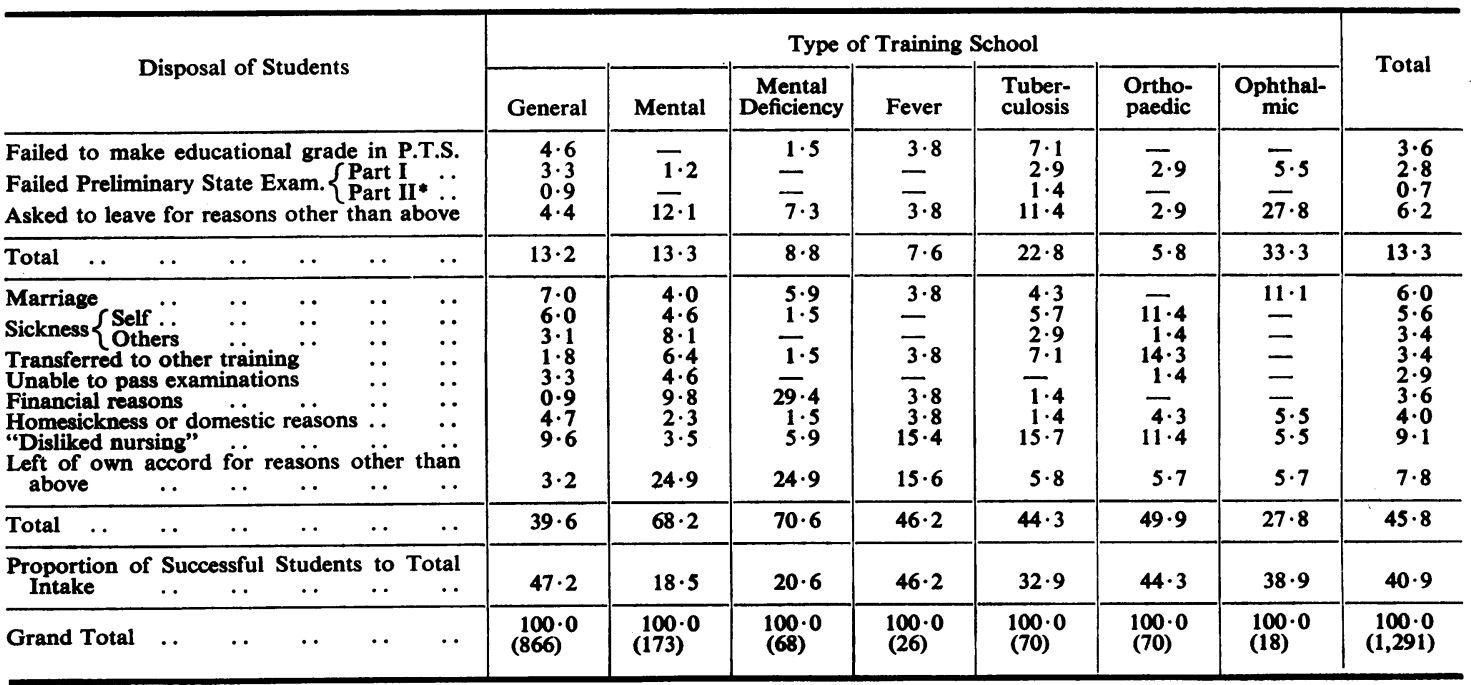

* This also includes failures where Parts I and II are taken together 
training schools these results agree very closely with those given in Table V. Two reasons may account for the much higher figure (53 per cent.) for the General training schools in Table V:

(a) the different proportions of voluntary and municipal hospitals in the two studies (the Working Party found a difference in the wastage rates from 35 to 43 per cent);

(b) the wastage rates given by the Working Party related to an annual intake over the war years when there was less freedom of movement from one occupation to another.

Table $\mathrm{V}$ also shows that the proportion of students leaving of their own accord (46 per cent.) is much greater than the proportion requested to leave before completion of training (13 per cent.). This is true of each type of school, except the ophthalmic training schools, in which the numbers involved are too small to be meaningful. Failure in examinations is the principal reason for requesting students to leave, and 7 per cent. of all students entering the schools in 1946 left for this reason. A further 3 per cent. left after failing examinations, though not requested to do so. This brings the overall proportion to 10 per cent. Sickness, either of the student or of her relatives, accounts for a further 9 per cent. of the total who leave before completion of training, and a further 4 per cent. leave because of homesickness or for domestic reasons other than illness. The 6 per cent. wastage due to marriage (all types of training) includes only students leaving to get married before completion of training.

In addition 6 per cent. of successful students (Table VI) leave to get married after completion of training, and hence the total marriage wastage figure (i.e. of qualified and unqualified nurses) is about 9 per cent.

On the other hand, 3.4 per cent. of all entrants transfer to other training and are not necessarily lost to the hospital service; the proportion of such students in the case of orthopaedic training schools is as high as 14 per cent. Although slightly less than 4 per cent. of all entrants leave for financial reasons, the proportions for mental and mental deficiency training schools are as high as 10 per cent. and 29 per cent. respectively. These schools admit greater numbers of male students than the others, and it is male students in the age group 20-29 who are most likely to leave for more remunerative employment. Unfortunately, the specification of one major reason for student wastage is very vague; students leaving because they "do not like nursing" and, indeed, for no stated reason merit closer study.

Table VI gives the results of an analysis of the subsequent disposal of students who successfully completed training. It shows that 72 per cent. of such students were retained in the hospital service, and those who leave to get married or for other reasons are not necessarily lost to the service. About three-quarters of those qualifying for the mental and mental deficiency registers remain in the hospital at which they received their training, whereas about one-quarter of those qualifying at the General training schools proceed to midwifery training.

\section{Length of Training}

In relation to causes of student wastage, an issue of considerable importance is the length of training received by students who did not complete training (Table VII, overleaf).

The percentage distributions differ by type of training school, but the numbers involved at training schools other than general and mental are too small to justify definite conclusions. Of students leaving before completion of training at General Training Schools, $48 \cdot 2$ per cent. left during the first 6 months and a further 19.5 per cent. during the second 6 months. Corresponding figures for Mental Training Schools show that 39 per cent. left during the first

TABLE VI

DISPOSAL OF SUCCESSFUL STUDENTS

Percentage Distributions by Type of Training School

\begin{tabular}{|c|c|c|c|c|c|c|c|c|c|c|c|c|c|}
\hline \multirow{2}{*}{\multicolumn{6}{|c|}{ Disposal of Students }} & \multicolumn{7}{|c|}{ Type of Training School } & \multirow{2}{*}{ Total } \\
\hline & & & & & & \multirow[b]{2}{*}{$\begin{array}{c}\text { General } \\
46 \cdot 3 \\
7 \cdot 1 \\
0 \cdot 2 \\
2 \cdot 2 \\
24 \cdot 2 \\
7 \cdot 3 \\
6 \cdot 6 \\
6 \cdot 1\end{array}$} & \multirow[b]{2}{*}{$\begin{array}{c}\text { Mental } \\
75 \cdot 0 \\
9 \cdot 4 \\
\frac{6 \cdot 25}{3 \cdot 1} \\
6 \cdot 25\end{array}$} & \multirow{2}{*}{\begin{tabular}{|c|}
$\begin{array}{c}\text { Mental } \\
\text { Deficiency }\end{array}$ \\
$78 \cdot 7$ \\
$7 \cdot 1$ \\
$\overline{7} \cdot 1$ \\
$\overline{7} \cdot 1$ \\
-
\end{tabular}} & \multirow[b]{2}{*}{$\begin{array}{c}\text { Fever } \\
8 \cdot 3 \\
8 \cdot 3 \\
\overline{41 \cdot 7} \\
\overline{1} \\
16 \cdot 7 \\
25 \cdot 0\end{array}$} & \multirow{2}{*}{$\begin{array}{c}\begin{array}{c}\text { Tuber- } \\
\text { culosis }\end{array} \\
- \\
= \\
\overline{-} \\
\overline{100 \cdot 0}\end{array}$} & \multirow{2}{*}{$\begin{array}{c}\begin{array}{c}\text { Ortho- } \\
\text { paedic }\end{array} \\
3 \cdot 2 \\
= \\
= \\
\bar{Z} \\
\begin{array}{c}93 \cdot 6 \\
3 \cdot 2\end{array}\end{array}$} & $\begin{array}{c}\begin{array}{c}\text { Ophthal- } \\
\text { mic }\end{array} \\
57 \cdot 1\end{array}$ & \\
\hline $\begin{array}{l}\text { Retained in ho } \\
\text { Took up app } \\
\text { another hosp } \\
\text { Joined H.M. F } \\
\text { Post-registratio } \\
\text { Midwifery } \\
\text { Marriage } \\
\text { Other reasons } \\
\text { Not specified } \\
\end{array}$ & $\begin{array}{l}\text { ospital } \\
\text { pointme } \\
\text { pital } \\
\text { Forces } \\
\text { on train } \\
\ldots \\
\ldots \\
\ldots \\
\end{array}$ & $\begin{array}{c}\text { ent as } \\
\ldots \\
\text { ning exc } \\
\therefore \\
\therefore \\
\cdots \\
\end{array}$ & $\begin{array}{l}\text { Staff } \\
\ldots \\
\text { cluding } \\
\ldots \\
\therefore \\
\cdots \\
\cdots\end{array}$ & $\begin{array}{l}\ddot{\text { Nurse }} \\
\ldots \\
\ddot{\text { midwife }} \\
\ldots \\
\cdots \\
\cdots \\
\end{array}$ & $\begin{array}{l}\dot{\text { in }} \\
\cdots \\
\ddot{\text { ery }} \\
\cdots \\
\cdots \\
\cdots \\
\cdots\end{array}$ & & & & & & & $\begin{array}{l}57 \cdot 1 \\
= \\
= \\
\overline{14 \cdot 3} \\
28 \cdot 6 \\
=\end{array}$ & $\begin{array}{r}43 \cdot 7 \\
6 \cdot 4 \\
0 \cdot 2 \\
3 \cdot 2 \\
18 \cdot 7 \\
6 \cdot 0 \\
16 \cdot 3 \\
5 \cdot 5\end{array}$ \\
\hline $\begin{array}{c}\text { Totals } \ldots \\
\end{array}$ & . & $\cdots$ & $\cdots$ & $\cdots$ & $\cdots$ & $\begin{array}{l}100 \cdot 0 \\
(410)\end{array}$ & $\begin{array}{l}100 \cdot 0 \\
(32)\end{array}$ & $\begin{array}{l}100 \cdot 0 \\
(14)\end{array}$ & $\begin{array}{l}100 \cdot 0 \\
(12)\end{array}$ & $\begin{array}{l}100 \cdot 0 \\
(23)\end{array}$ & $\begin{array}{l}100 \cdot 0 \\
(31)\end{array}$ & $\begin{array}{l}100 \cdot 0 \\
(7)\end{array}$ & $\begin{array}{l}100 \cdot 0 \\
(529)\end{array}$ \\
\hline
\end{tabular}


TABLE VII

LENGTH OF TRAINING OF UNSUCCESSFUL STUDENTS

Percentage Distributions by Type of Training School

\begin{tabular}{|c|c|c|c|c|c|c|c|c|c|c|}
\hline \multirow{2}{*}{\multicolumn{3}{|c|}{$\begin{array}{l}\text { Length } \\
\text { of Training }\end{array}$}} & \multicolumn{7}{|c|}{ Type of Training School } & \multirow[b]{2}{*}{ Total } \\
\hline & & & General & Mental & $\begin{array}{c}\text { Mental } \\
\text { Deficiency }\end{array}$ & Fever & Tuberculosis & Orthopaedic & Ophthalmic & \\
\hline \multicolumn{3}{|c|}{ 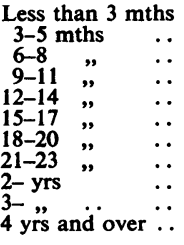 } & $\begin{array}{r}20 \cdot 5 \\
27 \cdot 7 \\
9 \cdot 2 \\
10 \cdot 3 \\
8 \cdot 3 \\
3 \cdot 3 \\
5 \cdot 0 \\
5 \cdot 0 \\
6 \cdot 6 \\
3 \cdot 5 \\
0 \cdot 6\end{array}$ & $\begin{array}{l}18 \cdot 4 \\
20 \cdot 6 \\
12 \cdot 1 \\
14 \cdot 2 \\
7 \cdot 8 \\
4 \cdot 3 \\
4 \cdot 9 \\
2 \cdot 8 \\
7 \cdot 8 \\
4 \cdot 3 \\
2 \cdot 8 \\
\end{array}$ & $\begin{array}{r}11 \cdot 5 \\
5 \cdot 8 \\
13 \cdot 5 \\
21 \cdot 1 \\
15 \cdot 4 \\
7 \cdot 7 \\
9 \cdot 6 \\
5 \cdot 8 \\
1 \cdot 9 \\
7 \cdot 7\end{array}$ & $\begin{array}{l}30 \cdot 7 \\
23 \cdot 1 \\
\overline{23} \cdot 1 \\
= \\
= \\
7 \cdot 7 \\
15 \cdot 4 \\
=\end{array}$ & $\begin{array}{l}16 \cdot 3 \\
34 \cdot 9 \\
9 \cdot 3 \\
11 \cdot 6 \\
7 \cdot 0 \\
7 \cdot 0 \\
- \\
\overline{9} \cdot 3 \\
4 \cdot 6 \\
-\end{array}$ & $\begin{array}{l}45 \cdot 0 \\
10 \cdot 0 \\
17 \cdot 5 \\
-7 \cdot 5 \\
-5 \cdot 0 \\
2 \cdot 5 \\
7 \cdot 5 \\
5 \cdot 0 \\
-\end{array}$ & $\begin{array}{l}18 \cdot 2 \\
9 \cdot 1 \\
45 \cdot 4 \\
9 \cdot 1 \\
= \\
= \\
\overline{18} \\
=\end{array}$ & $\begin{array}{l}20 \cdot 7 \\
24 \cdot 0 \\
10 \cdot 8 \\
11 \cdot 5 \\
8 \cdot 3 \\
3 \cdot 7 \\
4 \cdot 9 \\
3 \cdot 8 \\
7 \cdot 3 \\
3 \cdot 6 \\
1 \cdot 4\end{array}$ \\
\hline Totals & $\cdots$ & . & $\begin{array}{l}100 \cdot 0 \\
(456)\end{array}$ & $\begin{array}{l}100 \cdot 0 \\
(141)\end{array}$ & $\begin{array}{l}100 \cdot 0 \\
(54)\end{array}$ & $\begin{array}{l}100 \cdot 0 \\
(14)\end{array}$ & $\begin{array}{l}100 \cdot 0 \\
(47)\end{array}$ & $\begin{array}{l}100 \cdot 0 \\
(39)\end{array}$ & $\begin{array}{l}100 \cdot 0 \\
(11)\end{array}$ & $\begin{array}{l}100 \cdot 0 \\
(762)\end{array}$ \\
\hline
\end{tabular}

6 months, and that $26 \cdot 3$ per cent. left during the second 6 months.

It will be noted that in the training schools as a whole 44.7 per cent. of students leaving before completion of training did so in the first 6 months and $22 \cdot 3$ per cent. in the second 6 months. A further 20.7 per cent left during the second year; the Table shows the proportions leaving in subsequent yearly periods.

It is apparent, therefore, that the majority of students (two out of every three on this evidence) who fail to complete their course leave during their first year, and that the majority of these do so in the first 6 months.

\section{SUMmary}

The conclusions stated below are less comprehensive and more tentative than would have been those of an inquiry based on records pre-designed to explore all presumptively relevant types of information.

(1) Examination of the type of student entering a course of nurse training at hospitals of the Birmingham Region shows that before the minimum age of entry of 18 years was laid down, large proportions of students entering fever, orthopaedic, and ophthalmic training schools were under 18 years of age. Such students were more likely to leave than older entrants.

(2) Almost half the students entering the schools in 1946 were known to have received only the minimum of education, and the figures show a relatively high degree of wastage for this class of student.

(3) Success rates were far higher than average among students with previous nursing experience.

(4) Wastage levels in the various types of training school are given. The wastage rate of 82 per cent. for mental training was notable (the overall figure was 59 per cent.).

(5) Two out of every three students who failed to complete the course left during their first year, and of these the majority left in the first 6 months.

\section{REFERENCES}

General Nursing Council and Ministry of Health (1951). "Nurses Rules, Approval Instrument, 1951". Statutory Instruments, 1951; No. 1372. H.M.S.O., London.

Ministry of Health. Department of Health for Scotland. Ministry of Labour and National Service (1947). "Report of the Working Party on the Recruitment and Training of Nurses." H.M.S.O., 